\title{
CORPORATE SOCIAL ACTIVITIES IN GERMANY: THE EXPERIENCE OF COMPANIES
}

\author{
Tetiana Galetska' ${ }^{1}$, Natalia Topishko², Ivan Topishko ${ }^{3}$
}

\begin{abstract}
The purpose of the article is to study the European experience of the formation and regulation of socially responsible behaviour of economic entities; distinguishing the dominant drivers of corporate social responsibility in Germany and strategic priorities for its implementation. Its contents are interpreted in the expanded and narrow sense. Expanded approach insists that CSR is a set of interrelated types of responsibility (legal, economic, professional, moral, political, etc.) that reflect the system of values of society. Narrow interpretation foresees the definition of the degree (measure) of adoption by the subject of socially significant goals of society, the fulfilment of mutual rights and responsibilities, observance of social norms. The research subject - the peculiarities of the functioning of the European model of socially responsible entrepreneurship, the practice of its implementation in Germany. The methodology of the research is based on the definition of general principles of constructing the system of corporate social responsibility, disclosure the essence of the categorical apparatus, considering its main theoretical concepts. In the process of research, a set of methods of scientific cognition were used: analysis, synthesis, generalization (for the disclosure of the conceptual-categorical apparatus of the subject of the research); statistical method, grouping, empirical approach (while analysing the practice of distributing social responsibility among the subjects of social partnership in the EU for ensuring social protection of the population, and differences between the EU countries on the level of such responsibility of the subjects of the social process, depending on the model of socio-economic development). Conclusion. Under the influence of the challenges of globalization and the 4th Industrial Revolution, aggravation of competition, the conditions of the economy are changing. The need for business models on the basis of the strategy of sustainable development, socially responsible behaviour of business structures on the basis of systemic and long-term is growing. This situation actualizes the problem of creating mechanisms for maintaining social compromise in society. System of ensuring responsibility of the subjects of society for the formation of normal living conditions of society is one of the institutional mechanisms of social control and creating conditions for balancing personal, collective and social interests. Institutional support for the functioning of the mechanism for supporting social compromise regarding the formation of normal living conditions is based on the levers of state regulation (subsidies, preferential taxation, economic incentives, and compliance with the standards of activity); institute of entrepreneurship (international and national standards for doing business); institute of the public (the system of social reporting of enterprises, work with territorial communities). Compliance with product quality standards, with obligations to stakeholders, social reporting and progress reporting (including its environmental parameters), transparent business promotes the implementation of socio-stabilizing functions of entrepreneurial activity both on national and on a world scale. Experience of European (in particular, German) companies proves the need to adherence to the principles of social responsibility in entrepreneurship and the possibility of their use as a competitive advantage.
\end{abstract}

Key words: corporate social responsibility, sustainable development, Germany, international standards, social reporting, UN Global Compact, corporate social responsibility models.

JEL Classification: A13, M14

\footnotetext{
Corresponding author:

${ }^{1}$ National University of Ostroh Academy, Ukraine.

E-mail: tanya.galetska@oa.edu.ua

${ }^{2}$ National University of Ostroh Academy, Ukraine.

E-mail: natalya.topishko@oa.edu.ua

${ }^{3}$ National University of Ostroh Academy, Ukraine.

E-mail: ivan.topishko@oa.edu.ua
} 


\section{Introduction}

In nowadays difficult conditions, there is a change in the structure of the economy, mechanisms of management, development strategies and competition. The economic and political role of corporations is growing. Capital is actively migrating abroad. This reduces the tax base and the fullness of the state budget of the countries. Modern processes increase social risks, limit the state's ability to regulate socio-economic processes and maintain its stable dynamics, and to finance social commitments. The state sector in the social sphere reduces.

The social doctrine of the state is revised. Social responsibility between actors of social partnership is redistributed. It emphasizes on the necessity to strengthen the social and environmental components of entrepreneurial activity. The development of entrepreneurship is stimulated in the context of the Concept of sustainable development. At the World Economic Forum Davos-2012 (the theme of the forum "The Great Transformation: Shaping New Models"), models of growth and employment, leadership and innovation, resilience and resource utilization, social and technological models were discussed (World Economic Forum Annual Meeting, 2012). The focus was on the need for a global transformation that should begin with a renewed sense of social responsibility around the world. The problems of the formation of new world order, the 4th Industrial Revolution, the transformation of entire production and management systems, and the enhancement of social challenges were also discussed at Davos-2017 and defined by the theme of Davos 2018 discussions (World Economic Forum Annual Meeting, 2017). Such tendencies actualize the problem of mechanisms for achieving social compromise in society, social control over the business.

The object of the research is the processes of formation and implementation of socially responsible behaviour of business entities. The research subject the peculiarities of the functioning of the European model of socially responsible entrepreneurship, the practice of its implementation in Germany.

The purpose of the article is to analyse theoretical and methodological approaches to studying the European experience in the formation and regulation of socially responsible behaviour of economic entities; distinguish the dominant drivers of corporate social responsibility in Germany and strategic priorities for its implementation.

Objectives of the study: to find out the evolution of theoretical views and methodical foundations of the concept of social responsibility of business as an effective form of realization of its social component; determine the instruments of institutional influence of the state on compliance with the principles of socially responsible behaviour by business entities; find out the manifestation of the synergistic effect of the relationship of social responsibility of leading corporations in
Germany and adherence to the principles of sustainable development in their activities.

The following research methods were used in the paper: analysis, synthesis, and generalization method (for the disclosure of the conceptual and categorical framework of the subject of research); comparativehistorical method (when analysing the social function of the enterprise and the evolution of scientific views on its content); system method (in identifying institutional levers of state influence on compliance with the principles of socially responsible business of the business environment); statistical method (when processing data on the practice of the European Union regarding the distribution of fundamental rights and responsibilities between the actors of social partnership (citizens, employers and the state) in society regarding responsibility for ensuring social protection of the population).

Theoretical and practical aspects of corporate social responsibility (hereinafter - CSR) are well developed in the scientific literature. In particular, in works of D. Baden, J. Becker, H. Bowen, L. Brown, D. Henderson, R. Jenkins, A. Carroll, R. Norgaard, T. Hoskins, A. Scherer, and other prominent scholars. Most of the studies are dedicated to the definition of evaluation criteria and standards of socially responsible business behaviour. Relevant social practices have acquired certain forms of institutionalization. Taking into account the impact of extremely dynamic processes of the present, various aspects of this subject require further research. In this perspective, it is unquestioningly important and interesting to study the European experience in the implementation of the principles of corporate social responsibility.

\section{Theoretical foundations of corporate social responsibility as a social institution}

CSR is implemented in corporate governance certain type of social commitment (mostly voluntary) to employees, partners, the state, institutions of civil society, and society as a whole (Kolot, 2013). Social responsibility of the business is its "voluntary contribution to the development of society in the social, economic, and environmental spheres; is related to the main activity of the company and that goes beyond the legal minimum" (Corporate philanthropy. International dimension).

The idea of "social responsibility" has no clear definition. Its contents are interpreted in the expanded and narrow sense. Expanded approach insists that CSR is a set of interrelated types of responsibility (legal, economic, professional, moral, political, etc.) that reflect the system of values of society. Narrow interpretation foresees the definition of the degree (measure) of adoption by the subject of socially significant goals of society, the fulfilment of mutual 
rights and responsibilities, observance of social norms. Social responsibility is arbitrary; it is not a means of coercion. It can both motivate and limit the activities of the subject (Topishko, Topishko, Galetska, 2016).

The theoretical basis of corporate social responsibility as a model of economic activity was laid in the 50 years of the twentieth century by H. Bowen in the work "Social Responsibilities of the Businessman” (Bowen, 1953). In the 90-s of the XX century, there was a widespread introduction of these principles into business practice in order to obtain competitive advantages. The necessity to ensure sustainable development of both business structures and society as a whole is reflected in the evolution of this term. In the formation of the theoretical foundation of CSR as a social institution, the following stages are distinguished (Kolot, 2013):

- the basic concept of Corporate Social Responsibility (1950s-1970s). Developers: H. Bowen, K. Davis, A. Carroll, M. Schwartz;

- the concept of Corporate social responsiveness (1970s-1990s). A significant contribution was made by K. Ackerman, A. Bauer, D. Votaw, S. Sethi, A. Carroll, W. Frederick;

- Corporate Social Performance (CSP) (1980s-2000s). It was developed in the works of S. Sethi, A. Carroll, S. Wartick, P. Cochran, D. Wood, D. Swanson, and others.

The further development of the conceptual provisions of CSR took place in modern theories:

- "stakeholders" (which include employees, suppliers, buyers, shareholders, local community, media, shareholders, state and district authorities, the public, environmental advocates, government organizations, etc.); - "corporate accountability" (reporting on nonfinancial activities of the organization, social status of labour resources, etc.);

- "proactivity" (as a means of responding to modern challenges);

- "voluntary" (commitment of the subject to achieve long-term goals in which society is interested);

- "corporate citizenship" (the organization's activities associated with the realization of rights and obligations of individuals);

- "corporate sustainability" (assesses the social and economic impacts of the organization on the internal and external environment; new business strategies are developed from the standpoint of sustainable development (the so-called "The triple bottom line" of Elkington's sustainability (People, Planet, Profit)), etc.).

\section{Models of CSR and the main conditions for its implementation in the European Union}

Companies should coordinate their business activities with the principles of the concept of sustainable development in social, economic, and environmental spheres. Unlike philanthropy, charity and sponsorship as types of socially responsible business behaviour, this should be a "strategic approach to building relationships between firm and employees, partners and the public" (Mykhailina, 2015).

In most countries, CSR is mainly implemented by external pressure and more or less is encouraged/ regulated by the state. Formation of socially responsible behaviour of business entities occurs gradually. In the beginning, this is a warning, prophylactic measures, prevention of negative external externalities, compliance with social obligations. Further voluntary participation in solving social, environmental and other important social problems is encouraged. Economic, legal, and social responsibility to society becomes the highest level. CSR focuses on the internal environment (mainly on employees) and external (other "stakeholders": consumers, lenders, local communities, media, etc.).

Compliance with its principles has both positive consequences for business and negative (distracts funds and staff for non-economic goals). It is important that the goal of CSR should include not only increasing of profits, promotion of the brand, improving of the image, growth of the value of the company's shares ("corporate selfishness") but also its compliance on a long-term basis ("reasonable egoism"), taking into account all aspects of influence on "stakeholders" and society in general ("corporate altruism").

The conceptually elaborated social need for the observance of socially responsible behaviour by the agents of the economy has been practically implemented in its models. Depending on the role of the state and the mechanism of interaction between the subjects of social relations (the degree of its voluntary implementation), researchers conditionally point out such models of CRS as European, American, and Japanese. In the liberal American model (USA, Canada, English-speaking countries of Africa and Latin America), state intervention in the economy is limited. Social responsibility is realized mainly in the form of philanthropy, patronage, volunteering. It is voluntary and is considered to be the moral responsibility of the organization's leadership. This model is encouraged by the government in the form of tax reduction. It is supported by society. In the Japanese model, attention is directed to the company's internal environment. Although the role of the state is significant. A policy of equalizing households' incomes is being implemented. High level of collectivism is inherent to the social and economic problem-solving.

In a socially-oriented model of a market economy, social responsibility is an integral part of economic activity. The development and active implementation of social programs and social activity of the business are considered as a competitive advantage, conditions for a stable increase of living standards and minimization of social disproportions, the element of the mechanism of environmental management.

In Europe, there are three basic models of social responsibility (Kolosok, 2015): 
- Central Europe (Austria, Germany, France). The high degree of state regulation of social and labour relations is consistent with the preservation of the broad autonomy of enterprises and trade unions;

- Northern Europe (Belgium, Norway, Sweden). The state actively regulates social and labour relations at all three levels (person, business, state);

- Great Britain. It combines elements of the American and Continental European model.

The features of the model depend on the national and religious values of society, the peculiarities of the state policy, legal culture, traditions, priorities of the society, predominant ideological settings, ethics of economic activity (primarily labour and entrepreneurship relations). A significant influence on the model have also such impacts, as branch affiliation of the enterprise; the activity objectives and the specifics of the markets in which it operates; size and location; ethical principles of company owners; the degree of participation in international business, etc.

Statistical data, presented in Table 1, reflect the practice of distributing social responsibility among the subjects of social partnership in the EU for ensuring social protection of the population. Stability and progress of society are the results of economic efficiency and social compromise; achievement of a balance between the responsibility of the state to guarantee the socially normal conditions of reproduction of the workforce; the responsibility of the individual for the level and quality of life as a result of its own economic activity; the responsibility of the business for the results of its activities. As we see, the EU countries differ in the level of such responsibility of the subjects of the social process, depending on the model of socioeconomic development.

A characteristic feature of CSR in the European Union is the considerable information and certain financial support of business structures at the national and regional levels (Kirilyuk, 2015). In European law, the rules and regulations of socially responsible business behaviour are clearly prescribed and controlled by the state, such behaviour is one of the main features of a socially oriented model of development of the market economy. They regulate the economic, ecological, social activities of economic entities. The economic responsibility to the "stakeholders" is based on compulsory legal liability to the state and on the control over the economic activity of enterprises by public organizations. The social sphere is regulated on the basis of the Social Chapter of the Maastricht Treaty of 1992 (communication, safety, and health of workers, rights and working

Table 1

Distribution of responsibilities between social partners in some European Union countries for the payment of insurance premiums in 1997-2015 (Percentage of total receipts)

\begin{tabular}{|c|c|c|c|c|c|c|c|c|c|c|c|c|c|c|c|c|c|c|}
\hline \multirow[b]{2}{*}{ Indicator } & \multirow[b]{2}{*}{ Years } & \multicolumn{17}{|c|}{ Countries } \\
\hline & & 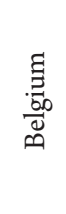 & 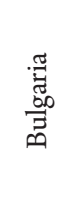 & 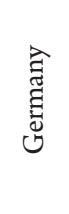 & 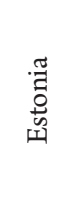 & 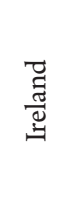 & $\begin{array}{l}\ddot{\Xi} \\
\ddot{\Xi} \\
\tilde{U}\end{array}$ & $\begin{array}{l}\text { ज्ञ } \\
\text { की }\end{array}$ & 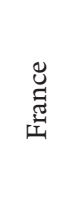 & 氞 & 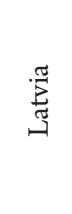 & $\begin{array}{l}\widehat{c} \\
\text { 离 } \\
\text { 焉 }\end{array}$ & 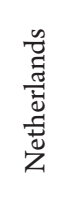 & 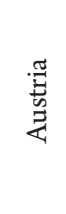 & 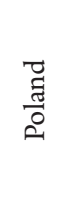 & 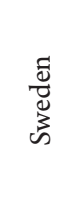 & 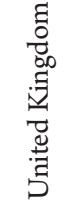 & $\begin{array}{l}\text { 恿 } \\
\text { 号 }\end{array}$ \\
\hline \multirow{5}{*}{$\begin{array}{l}\text { Employers' } \\
\text { social } \\
\text { contribution }\end{array}$} & 1997 & 46.8 & : & 37.6 & : & 23.1 & 37.7 & 51.6 & 46.6 & 51.0 & 51.8 & : & 20.6 & 39.5 & : & 39.2 & 26.1 & 23.8 \\
\hline & 2000 & 45.5 & : & 38.0 & 79.2 & 25.6 & 38.2 & 52.5 & 46.0 & 42.0 & 49.1 & 47.0 & 29.4 & 39.5 & 41.4 & 40.5 & 29.9 & 24.4 \\
\hline & 2005 & 43.7 & 42.3 & 35.1 & 79.0 & 26.9 & 35.4 & 49.4 & 44.7 & 41.3 & 46.3 & 42.0 & 33.3 & 37.9 & 39.6 & 40.7 & 34.8 & 31.0 \\
\hline & 2010 & 41.7 & 30.8 & 33.0 & 77.4 & 22.2 & 31.9 & 43.2 & 43.0 & 38.0 & 36.4 & 30.5 & 33.2 & 37.1 & 43.9 & 37.5 & 34.3 & 32.7 \\
\hline & 2015 & 40.6 & 31.4 & 34.3 & 78.3 & 30.2 & 32.3 & 41.4 & 42.0 & 34.6 & 41.2 & 40.3 & 30.1 & 36.2 & : & 37.7 & 25.8 & 31.5 \\
\hline \multirow{5}{*}{$\begin{array}{l}\text { Social } \\
\text { contribution } \\
\text { paid by the } \\
\text { employees }\end{array}$} & 1997 & 22.1 & $:$ & 29.2 & $:$ & 13.9 & 23.2 & 17.3 & 26.4 & 17.2 & 16.3 & $:$ & 43.7 & 27.3 & $:$ & 7.8 & 25.1 & 14.5 \\
\hline & 2000 & 22.4 & $:$ & 27.6 & 0.0 & 12.3 & 22.6 & 15.0 & 19.9 & 15.3 & 15.7 & 12.8 & 38.1 & 27.4 & 24.8 & 9.4 & 22.5 & 14.0 \\
\hline & 2005 & 22.0 & 18.6 & 27.8 & 0.4 & 13.3 & 22.9 & 14.1 & 20.9 & 15.1 & 16.5 & 15.9 & 34.5 & 27.4 & 22.4 & 8.8 & 14.0 & 14.0 \\
\hline & 2010 & 20.3 & 16.1 & 28.5 & 2.7 & 11.5 & 21.1 & 12.2 & 20.8 & 14.9 & 12.8 & 19.6 & 33.0 & 26.4 & 17.3 & 9.4 & 12.6 & 14.7 \\
\hline & 2015 & 15.2 & 15.3 & 22.9 & 1.1 & 7.9 & 18.0 & 8.0 & 12.6 & 8.4 & 16.9 & 23.8 & 32.0 & 20.9 & : & 8.5 & 10.1 & 15.4 \\
\hline \multirow{5}{*}{$\begin{array}{l}\text { General } \\
\text { government } \\
\text { contribution }\end{array}$} & 1997 & 27.3 & $:$ & 30.3 & $:$ & 62.9 & 29.6 & 27.9 & 23.9 & 29.8 & 32.0 & $:$ & 16.5 & 32.2 & $:$ & 46.3 & 48.0 & 60.8 \\
\hline & 2000 & 29.1 & $:$ & 32.1 & 20.6 & 60.8 & 29.2 & 29.9 & 30.4 & 40.7 & 35.2 & 31.6 & 14.4 & 31.8 & 21.6 & 45.8 & 46.4 & 60.5 \\
\hline & 2005 & 32.0 & 35.9 & 35.2 & 20.5 & 54.9 & 30.6 & 34.3 & 30.6 & 42.0 & 36.6 & 34.8 & 20.0 & 33.2 & 21.4 & 48.3 & 49.6 & 54.1 \\
\hline & 2010 & 35.6 & 51.3 & 36.7 & 19.7 & 63.1 & 35.6 & 43.6 & 34.1 & 45.5 & 48.6 & 37.4 & 26.0 & 34.8 & 18.3 & 51.2 & 45.6 & 52.8 \\
\hline & 2015 & 37.5 & 47.4 & 33.5 & 20.6 & 57.9 & 39.6 & 43.8 & 35.7 & 48.5 & 41.5 & 36.4 & 23.4 & 36.3 & : & 50.7 & 58.3 & 53.0 \\
\hline \multirow{5}{*}{$\begin{array}{l}\text { Other } \\
\text { receipts }\end{array}$} & 1997 & 3.7 & : & 2.9 & $:$ & 0.2 & 9.6 & 3.2 & 3.1 & 2.0 & 0.01 & $:$ & 19.2 & 1.1 & $:$ & 6.7 & 0.8 & 1.0 \\
\hline & 2000 & 3.0 & $:$ & 2.3 & 0.2 & 0.3 & 10.0 & 2.7 & 3.8 & 2.0 & 0.01 & 8.7 & 18.1 & 1.3 & 12.2 & 4.3 & 1.2 & 1.1 \\
\hline & 2005 & 2.3 & 3.2 & 2.0 & 0.1 & 4.9 & 11.1 & 2.2 & 3.8 & 1.6 & 0.7 & 7.3 & 12.2 & 1.5 & 16.7 & 2.2 & 1.6 & 0.04 \\
\hline & 2010 & 2.4 & 1.8 & 1.8 & 0.2 & 3.2 & 11.3 & 1.1 & 2.1 & 1.6 & 2.2 & 12.2 & 7.8 & 1.8 & 20.5 & 2.0 & 7.5 & 0.04 \\
\hline & 2015 & 2.2 & 1.8 & 1.8 & 0.1 & 2.9 & 5.7 & 1.9 & 3.1 & 1.9 & 0.4 & 0.1 & 14.2 & 1.2 & : & 2.1 & 1.6 & 0.1 \\
\hline
\end{tabular}

Source: Social protection receipts by type (2018). Retrieved from: https://ec.europa.eu/eurostat/web/products-datasets/-/TPSO0108 
conditions). Environmental aspects of CSR have been taken into account in many legislative documents that are fundamental to government programs. For example, Environmental Impact Assessment (EIA), Environmental Management and Audit Scheme (EMAS), Integrated Product Policy (IPP), etc.

In 1996, the European Business Network for Corporate Social Responsibility (CSR Europe) was created. The main conditions for the implementation of CSR in Europe are set out in the Green Paper (2001) entitled "Promoting a European framework for Corporate Social Responsibility”. CSR is defined as a system that serves as a basis for companies that voluntarily integrate social and environmental issues into their business activities and interact with "stakeholders". The Green Paper sets out the goals, ideas, and ten main CSR principles, which are outlined in the Global Compact (The Ten Principles and the Global Compact). It is also outlined in this document the procedures and practices of conducting socially responsible business (organizational management, human rights, labour relations, ethical operational activities, environmental protection, protection of consumer rights, development of territorial communities, and cooperation with them).

\section{The practice of public stimulation of CSR in Germany}

Germany supports the widespread initiative of the European Union's CSR. The state encourages the implementation of social programs for the interaction of companies with local communities on a strategic basis (CSR in Deutschland). In 2009, the National CSR Forum was launched, the task of which is to develop a CSR strategy. In 2010, the National CSR Action Plan was adopted. Various ministries and government organizations contribute to the implementation of the national CSR strategy. Its realization is coordinated by the Federal Ministry of Labour and Social Affairs (BMAS) (Bundesministerium für Arbeit und Soziales (BMAS)). Federal Government CSR Bonus is an effective incentive to adhere to principles of socially responsible business, to integrate social and environmental commitments into the corporate culture. In 2017, Award "CSR. Made in Germany" of the Federal Government for adhering socially responsible business on a long-term basis received in different categories:

- up to 300 people: the company "Gundlach Bau und Immobilien" (sphere of activity - construction, modernization, leasing of real estate, property management) for practical achievements in integrating social and environmental commitment into the corporate culture;

- up to 1000 people: "Rapunzel Naturkost" (agrarian sector) for successful strategic corporate governance based on the principles of sustainable development (social values, ecology and culture);

- over 1000 people - the international company "Grohe AG" (sanitary technologies) for a socially, environmentally and economically responsible corporate governance (CSR. CSR-Preis, 2017).

The list of companies that most successfully adhere to the principles of CSR in their business activity is systematically posted in the media (Herausragende Praxisbeispiele für Soziale Verantwortung der Unternehmen - CSR). Germany is a member of the European Sustainable and Responsible Investment Forum, created with the purpose of promoting sustainable development and responsible social investment in Europe (The European Sustainable and Responsible Investment Forum).

Since 2016, mandatory reporting on CSR has been implemented for some enterprises. It is an integral part of financial reports (Facts about Germany: foreign policy, society, science, economy, culture, 2015, p. 58). Social (non-financial) report combines environmental, social, managerial aspects of the company's activities. Its standards are a system of criteria, principles, methodological recommendations for measuring the performance of companies from the social and ethical positions. This system is a basis of the international AA-1000 (AccountAbility) and developed by the Institute of Social and Ethical Accountability "AccountAbility") (AccountAbility). According to the law "On Social Report", it is implemented regular reporting by companies with more than 300 employees regarding the relationship with employees and with the local community. These reports are compulsory for companies, which trade in stocks in the stock market. Non-financial reporting of economic entities is taken into consideration by savings and pension funds in their investment process.

Social audit of economic entities includes the analysis of the composition of the employees; working-time and rest time; compensation to employees and its accordance with the average level of the region; sanitary conditions; compliance with the international standards of the quality system of products (ISO 9000), the level of health and professional safety of employees (OHSAS 18001), environmental standards (ISO 14000), etc. The SA-8000 series of standards are based on the ethical principles of the ILO Conventions, the Universal Declaration of Human Rights and other documents, which regulate human rights. In 2010, the international standard ISO 26000 Social Responsibility Guide (ISO / DIS 26000: Guidance on social responsibility) wasimplemented.Itstresses on the necessity of achievement of socially responsible behaviour of organizations of all types in different countries. The principles of its observance are declared on a voluntary basis.

An integral element of the concept of socially responsible business behaviour is corporate social insurance as a component of the social package. It not 
only protects workers from life's troubles but also creates the company's positive image as a socially responsible entity, serves as an additional motivational factor for staff (Barannik, 2011).

For European companies, patronage, as a form of CSR, is not a leading one. Charity activity is regulated legally. In case of the implementation of such activities, German companies obtain a special certificate, according to which the organization can reduce their tax base by the amount spent. The task is to modernize the processes of charity in order to reduce the cost of administration.

As an example of socially responsible behaviour of actors of globalization serve social reports of a large number of huge European corporations, in particular, German ones. It is published in the special annual edition "Giving in Numbers" CECP (The CEO Force for Good). The experience in the social strategy of global leaders and improvement of social dialogue for creating favourable conditions of society livelihood are summarized. In 2016 editions were published the results of the research on how corporate social programs of collaboration with employees contributed to the financial success of the 272 world's leading companies (Giving in Numbers, 2016). In the 2017 report (CECP / GIVING IN NUMBERS: 2017 EDITION), there is an analysis of the corporate philanthropy profile and the main trends of corporate social investment of 258 transnational companies (Giving in Numbers, 2017). International corporations must adhere to the ILO labour standards, the provisions of the UN Global Compact, and the OECD Guiding Principles. Companies must meet the expectations of "stakeholders" regarding economic, social, environmental responsibility in both short- and long-term periods.

In its international activities, German concerns must adhere to the 17 goals of sustainable development outlined in the Action Plan 2030 at the 70th General Assembly of the United Nations in 2015. This document expanded the Millennium Development Goals (MDGs) of the United Nations, which determined the development of new industrialized and developing countries for the period from 2000 to 2015 (Facts about Germany: foreign policy, society, science, economy, culture, 2015, p. 58).

\section{The experience of German transnational corporations in using CSR as a competitive advantage}

An example of changing the role of business in a society based on the formation of a new consciousness, the inclusion of social and environmental initiatives on a long-term basis in the strategic goals of the organization, their coordination with economic activity, taking into account the interests of "stakeholders" can serve large corporations in Germany. The public, company investors, and other stakeholders can expect responsible actions and sustainable solutions from them. One of the first German companies that used CSR as a competitive advantage and commercial success was the large pharmaceutical company Betapharm. In the 90s of the XX century, the company has increased sales in the country's highly saturated pharmaceutical market and has succeeded thanks to implementing a strategic social program for families with chronically ill children.

The transnational German chemical concern BASF, headquartered in Ludwigshafen (Rhineland-Palatinate), specializes in the production of a wide range of products (plastic, paint, cosmetics, food additives, technical and building chemicals, fine chemicals, agricultural products, etc.) (BASF Online Report, 2016; CSR in Unternehmen Beispiele). The company focuses on achieving high economic efficiency, adherence to the principles of social responsibility, environmental protection. The company's management identified six core values that became a part of the organization's goals: security, health, environmental protection, mutual respect, open dialogue and integrity. Taking into account the specifics of production processes, the organization carries out special measures for the safety and health of workers.

Considering BASF's international status, its social commitments are focused on supporting the education of the younger generation in the regions of the world where consolidated subsidiaries of the concern are located; cooperation with local communities, institutions, associations; humanitarian cooperation. In particular, it promotes the study of German among young children, school sponsorship in the region, and projects aimed at increasing the interest of children in scientific disciplines. Own day centres were organized for children in order to improve for their parents compatibility for family and work. Publication of annual social reports on compliance by the company with the model of strategic CSR allows it to position itself as a corporate citizen (the theory of "corporate citizenship"), not indifferent to the socio-economic and environmental problems of the region. The loyal attitude of employees, consumers, and investors to the company's activities is the achievement of the company. However, the environmental hazard of the company, despite its compliance with the conditions, creates a significant concern of the public.

German company Deutsche Post DHL (transport and logistics) is recognized as an expert in corporate communications solutions (CSR in Unternehmen Beispiele; Deutsche Post DHL Group). Management and personnel of the company adhere to the Code of Conduct on the basis of group values, which since 2006 is mandatory for all regions where its affiliates and business units are located. Deutsche Post World Net has an agreed concept of CSR. It relies on its core competency (for example, logistics for eliminating the consequences of natural disasters) and thus 
maximizes the benefits of its commitment to society and the company. In order to protect the environment, Deutsche Post DHL is replacing freight transport by rail, purchasing environmentally friendly vehicles. The company cooperates with the UN to create a global network of disaster response teams. Collaborates with the charity "Aktion Mensch". Makes donations for educational institutions in the Global South. DHL has its own private university in Shanghai (China).

Deutsche Bankoperates in the financial services market (CSR in Unternehmen Beispiele; Deutsche Bank). The condition of the economic success of the bank is the trust of society. The company's social activities are focused on five areas (social innovation, education, corporate volunteer programs, arts, sustainable development). Social responsibility is considered as a contribution to both their own development and development of society. The principles of socially responsible behaviour are respected by the company both in the internal and external environment. Internal staff is provided for employees. There is an e-learning platform and also international scholarship programs are provided. The functioning of various professional pension schemes and own kindergartens are organized. One of the areas of social interaction of the organization is the support of musical and artistic organizations. The environmental programs of Deutsche Bank are aimed at economical consumption of electricity, water, and paper.

German transnational corporations (like other enterprises) support the project "CSR. Made in Germany", the main aim of which is to form and implement a national idea of achieving a high degree of socially responsible behaviour by domestic businesses (CSR Made in Germany). This strategic vision of CSR ensures the systematic socio-economic relations, reflects the fundamental values of society, shapes the ethical principles of the behaviour of the subjects of social partnership, and opens up new perspectives.

\section{Conclusions}

Modern society is under the influence of multi-vector changes that increase the asymmetry of the economy and social development. The need for business models on the basis of the strategy of sustainable development, socially responsible behaviour of business structures on the basis of systemic and long-term is growing. In a socially oriented model of a market economy, the ability of corporations to perceive social requests is flexible, multidirectional, and geared towards stakeholders (workers, shareholders, authorities, investors, consumers, and the public). It is stimulated by the state strategy of its regulation, social reporting, and strong public pressure. The implementation of various social programs, the functioning of the various forums, enables CSR to be disseminated and adhere to its principles, which become extremely important in the face of globalization and the need to maintain sustainable development. Experience of the functioning of European (in particular, German) corporate social responsibility model is beneficial for the countries that implement it.

The main obstacles to dissemination of CSR in Ukraine are:

- declarative activity, impossibility to control the purposeful use of funds;

- lack of unification of standards, criteria for assessing the company's social responsibility;

- the imperfection of the relevant legislation;

- low level of corporate culture, insufficient development of charity and social activity;

- the financial and economic weakness of a significant proportion of economic entities, their orientation to survival;

- legal nihilism and deformation of legal consciousness in compliance with current legislation;

- the closeness of the information of the majority of business entities to the general public;

- the passivity of the public.

\section{References:}

AccountAbility. Retrieved from: http://www.accountability.org

Barannik, L. B. (2011). Sotsialnyi paket yak atrybut suchasnoho pidpryiemnytstva [Social package as an attribute of modern entrepreneurship]. Visnyk KNU imeni Tarasa Shevchenka, 124-125, 62-65.

BASF Online Report (2016). Retrieved from: http://bericht.basf.com/2016/en/

Bowen, H. R. (1953). Social Responsibilities of the Businessman. Harper \& Row - N. Y., p. 6.

Bundesregierung. Bundesministerium für Arbeit und Soziales (BMAS). Retrieved from: https://www.bmas.de/ $\mathrm{DE} /$ Startseite/start.html

CSR. CSR-Preis (2017). Retrieved from: www.csr-in-deutschland.de/DE/CSR-Preis/csr-preis.html

CSR in Deutschland. Retrieved from: www.csr-in-deutschland.de/DE/Startseite/start.htm

CSR in Unternehmen Beispiele. Retrieved from: http://www.global-ethic-now.de/gen-deu/0d_weltethos-undwirtschaft/0d-04-verantwortung/0d-04-200-csr.php

CSR Made in Germany. Retrieved from: https://www.csr-in-deutschland.de/EN/Home/home.html

Deutsche Post DHL Group. Retrieved from: https://www.deutschepost.de/en/home.html

Deutsche Bank. Retrieved from: https://www.deutsche-bank.de/pk.html

Fakty pro Nimechchynu: zovnishnia polityka, suspilstvo, nauka, ekonomika, kultura: dovidnyk [Facts about Germany: foreign policy, society, science, economy, culture: reference book]. Retrieved from: https://www.tatsachen-ueber-deutschland.de/en 
Giving in Numbers (2016). Edition Trends in Corporate Community Engagement. Retrieved from: http://cecp.co/wp-content/uploads/2016/11/GIN2016_Finalweb.pdf?redirect=no

Giving in Numbers (2017). Edition Trends in Corporate Community Engagement. Retrieved from: http:P/cecp.co/home/resources/giving-in-numbers/

Herausragende Praxisbeispiele für Soziale Verantwortung der Unternehmen - CSR. Retrieved from: http://www.csrgermany.de/www/csr_cms_relaunch.nsf/res/Liste_sozial_engagierter_Unternehmen.pdf/\$file/ Liste sozial engagierter Unternehmen.pdf

ISO / DIS 26000: Guidance on social responsibility. Retrieved from: https://www.iso.org/iso-26000-socialresponsibility.html

Kirilyuk, N. V. (2015). Korporatyvna sotsialna vidpovidalnist: dosvid yevropeiskykh kompanii [Corporate social responsibility: the experience of European companies]. Molodyi vchenyi, 2(2), 107-111.

Kolosok, A. (2015). Zarubizhnyi dosvid sotsialnoi vidpovidalnosti biznesu ta perspektyvy yoho zastosuvannia $\mathrm{v}$ Ukraini [Foreign experience of social responsibility of business and prospects of its application in Ukraine]. Ekonomichnyi chasopys Skhidnoievropeiskoho natsionalnoho universytetu imeni Lesi Ukrainky, 1, 15-19.

Kolot, A. (2013). Suchasna filosofiia korporatyvnoi sotsialnoi vidpovidalnosti: evoliutsiia pohliadiv [Modern philosophy of corporate social responsibility: evolution of attitudes]. Ukraina: aspekty pratsi, 8, 3-17.

Korporatyvnaia fylantropyia. Mezhdunarodnyi aspekt [Corporate philanthropy. International dimension]. Retrieved from: https://www.slideshare.net/evd_oa/ss-37536147

Mykhailina, Z. (2015). Dosvid sotsialno vidpovidalnoho biznesu: praktyka FRN [The experience of a socially responsible business: practice of the Federal Republic of Germany]. Materialy naukovo-praktychnoi konferentsii «Upravlinnia sotsialno-ekonomichnym rozvytkom v umovakh hlobalizatsii ». Ivano-Frankivsk: IFNNIM TNEU, p. 28-30.

Social protection receipts by type (2018). Retrieved from: https://ec.europa.eu/eurostat/web/productsdatasets/-/TPS00108

The European Sustainable and Responsible Investment Forum. Retrieved from: https://www.eurosif.org/

The Ten Principles and the Global Compact. Retrieved from: https://www.unglobalcompact.org/what-is-gc/ mission/principles

Topishko, I. I., Topishko, N. P., Galetska, T. I. (2016). Sotsialna vidpovidalnist pidpryiemstva v Ukraini: problemy zabezpechennia ta shliakhy pidvyshchennia [Corporate social responsibility in Ukraine: problems of security and improvement ways]. Prychornomorski ekonomichni studii, 12(1), 95-99.

World Economic Forum Annual Meeting (2012). Retrieved from: http://reports.weforum.org/davos-2012/

World Economic Forum Annual Meeting (2017). Retrieved from: https://www.weforum.org/events/worldeconomic-forum-annual-meeting-2017 